Article

\title{
Application of Specific Mathematical Methods in the Context of Revitalization of Defunct Intermodal Transport Terminal: A Case Study
}

\author{
Ján Ližbetin * and Ondrej Stopka® \\ Department of Transport and Logistics, Faculty of Technology, Institute of Technology and Business in České \\ Budějovice, Okružní 517/10, 37001 České Budějovice, Czech Republic; stopka@mail.vstecb.cz \\ * Correspondence: lizbetin@mail.vstecb.cz
}

Received: 18 February 2020; Accepted: 13 March 2020; Published: 15 March 2020

check for updates

\begin{abstract}
The article deals with a specific research study discussing the possibility to revitalize a specific non-functional intermodal transport terminal. The structure of the manuscript consists of five sections. The first part is focused on the analysis of the subject being investigated in important scientific publications. The second part of the article presents a brief analysis of the current situation concerning intermodal transport in the Czech Republic and emphasizes the need to build an intermodal transport terminal in the South Bohemia region. The third section describes the contemporary state of the Nemanice transshipment station, provides a calculation of the terminal transport potential, which is thereafter used in the next paper section in order to design individual terminal elements. The objective of this study is to propose an approach methodology regarding the terminal connection to railway and road infrastructure, necessary quantification of the transport potential, which subsequently defines the operational need for handling equipment, and other parameters of the terminal fundamental elements. This methodological guideline is based on variant recommendations to equip the terminal with various handling devices, which are then evaluated, applying the exact decision making methods. Such an evaluation is included in the fourth part of the article. Here, the authors try to find out which terminal equipment is the most appropriate in terms of overall terminal efficiency. The last part of the manuscript is devoted to the final discussion of the key findings and conclusion containing an insight into potential future projects or studies to be addressed.
\end{abstract}

Keywords: intermodal transport; transshipment; intermodal transport terminal; revitalization; mathematical methods; multi-criteria decision making; multi-criteria analysis

\section{Introduction}

In today's globalized market, rapid delivery and transport efficiency play an important role. As the volume of goods transported over long distances has increased over the years, the reliability of the transport system is emphasized. Thereby, the need to regulate freight transport and modal split among individual modes of transport arises [1]. Thus, the high energy consumption of road transport and the social responsibility towards the environment provide the opportunity to develop intermodal transport [2].

Intermodal transport is such multimodal transport (i.e., uses at least two modes of transport) in which goods are loaded into an intermodal transport unit (container, swap body, semi-trailer, or articulated vehicle) while not handling the very goods during the transport mode shift, but the whole intermodal transport unit is transshipped. In order to maximize the efficiency of intermodal transport and facilitate transshipment handling among individual transport modes, it is necessary to cover the territory with sufficient and high-quality infrastructure, which can include the transport network and especially the intermodal transport terminals [3]. 
Intermodal transport terminals are places/sites where the mode of transport changes. They are one of the most important elements of logistics chains. The efficiency of the transport-logistics chain depends on the efficiency of every single element of the chain. Therefore, the equipment, layout, and technology of the terminal are to be designed in order not to create a bottleneck. According to the authors in [4], the default parameters of a terminal are as follows:

- $\quad$ requirements for performance and service;

- the size of the transshipment area including the depositing areas;

- the number, length, and layout of railway tracks (including handling tracks);

- the connection to the transport network (roads, railways, waterways);

- the number, type, and technical parameters of reloading (handling) mechanisms.

The specific parameters of each terminal are determined by its operator, however, it essentially depends on the volume of planned services provided and its location [5]. Although no legislation stipulates the technical parameters of transshipment facilities [6], they should comply with the operational requirements of the European Agreement on Important International Combined Transport Lines and Related Installations (hereinafter referred to as AGTC) [7].

The subject of intermodal transport terminal designs has been addressed by a series of distinguished authors in this field of research. A detailed overview of some of the most relevant publications can be found in the following Section 2. Based on the analysis conducted, it can be stated that most of the studies are focused on the topic of seeking a suitable terminal location, or similar logistics objects in a certain territory. These publications discuss different methodologies for locating the terminal when taking into account various defined factors and criteria. This subject is, nevertheless, tackled to a limited measure, which is considered to be a gap in the methodologies published in professional and scientific journals.

Therefore, we focus on outlining possible procedures (design of the specific methodological guideline), according to which, it is possible to proceed when designing the construction of a terminal in a certain location. As far as the very methodology is concerned, the authors search for an answer to the question of what type of handling equipment is the most advantageous for the given terminal in terms of overall efficiency.

Certainly, the authors realize that this represents only one of the numerous possible insights into the examined topic and do not avoid discussing other potential scenarios in the future. The methodology is virtually applied to the locality of the South Bohemia region (in the Czech Republic). At present, this location is highly topical in the Czech Republic in terms of intermodal transport development. The first working meeting was held in the city of České Budějovice (center of the South Bohemia region) in 2015 regarding the possible revitalization of the transshipment station in the Nemanice industrial site. The working meeting was attended by representatives of the operators of intermodal transport, Railway Administration of the Czech Republic, national railway carrier ČD Cargo, Česmad Bohemia company, the South Bohemia region, as well as universities specialized in transport fields of study. The authors of this manuscript were members of this working group, and all the data used in this research study are based on the documents of the meeting, i.e., it was discussed and verified with other members.

The structure of the article consists of five parts. Its first section is devoted to the analysis of an examined topic in numerous relevant publications. The consequent section contains a brief analysis of the latest state of intermodal transport in the Czech Republic and demonstrates a need to build an intermodal transport terminal in the South Bohemia region, in particular, in the Nemanice locality. The following two parts of this research study compile the very methodology related to the design of terminal elements. The draft methodology is based on several scenarios proposing the particular terminal equipment with various handling elements, which are then evaluated using the exact decision making techniques. This evaluation is conducted in the fourth section of the article. The last part of the 
manuscript is devoted to the final discussion of the key findings and conclusion containing an insight into potential future projects or studies to be addressed.

In the manuscript, we show that it is possible to address the problems of designing or revitalizing transport terminals by using optimization-mathematical methods. The outcome of the investigation itself is to design the most suitable type of handling system in terms of efficient operation. The authors' view of efficiency is focused on equipment operating costs so that the terminal's economic operation is as viable as possible, thus ensuring the sustainability and competitiveness of the operated premises. To this end, we chose primarily economic aspects while multi-criteria decision making process.

The designed methodology provides a reasonable view of the choice of terminal elements from determining the required number of handling devices to specifying the most appropriate type of such equipment, while taking into consideration overall economic efficiency. The terminal will thus be sufficiently equipped in terms of performance and, simultaneously, its operation will be cost-effective and sustainable. The sustainability of intermodal transport infrastructure positively affects the sustainability of the entire transport system. An efficiently operated transport hub (where an intermodal transport terminal can be included) is an essential prerequisite for ensuring the sustainability of the transport system in a certain territory, and therefore, the proposed methodology for addressing the modernization of defunct intermodal transport terminals is closely related to the sustainability of freight transport per se, above all, in terms of the sustainable development of freight transport performance in a globalized world.

\section{Literature Review}

The basic document addressing the issue of intermodal transport in Europe is the AGTC agreement [7]. In Annex II., it contains a list of objects (terminals) in the territory of individual states participating in the agreement. The list of terminals within the Czech Republic is based on a historical principle (in compliance with the construction of original container transshipment stations of the Czechoslovak Railways). In Annex IV., the agreement also stipulates technical-technological requirements for terminals, including business neutrality. This means the non-discriminatory access to individual customers by the terminal operator.

To a greater or lesser extent, several authors have addressed the issue of building intermodal transport terminals, for example, [8-18].

The article [14] deals with a container terminal in the Bangkok port. Based on the analysis of container flows through the terminal within a time period of 16 years, the authors try to predict the development of transported containers' volume until 2041. The analysis results are thereafter utilized as a fundament for planning the further container terminal development in this particular port. Last but not least, the authors state that the forecast regarding the future number of containers in the port is imperative in order to model efficient terminal development. Such a methodology is based primarily on the thorough and precise prediction of transshipped container volumes.

The subject of classification of seaports is discussed in the publication [15]. Specifically, the authors are focused the situation in the classification of ports (as part of the global logistics chain) in Malaysia, wherein the paper objective is to modify a current classification framework concerning the Malaysian ports in view of global measure via improving the port/terminal coordination system at a national scale. Applying the descriptive analysis qualitative approach, the fundamental of such an improved system was to emphasize segregation of different port/terminal classes. This study also suggests a sustainable guideline when decision making on the enlargement of port/terminal competitiveness via port activities' reclassification.

Other authors are aimed at the issue of energy efficiency and sustainability of ports and transport terminals [16]. These days, many such objects strive to improve their energy efficiency since prices for energy have been increasing rapidly for some time and, for the logistics sector, environmental changes have been crucial targets to be coped with. In line with the above, the manuscript provides a comprehensive literature review to summarize various strategies, renewable energy sources, alternative 
fuel options, as well as environmental management systems to help move towards the port/terminal energy efficiency and sustainability.

In the research study [17], an interesting view of the terminal design in a particular territory is described. Specifically, this article presents identification of the terminal location to be the most suitable for a variety of stakeholders. These parties often have counterproductive intentions and ideas, hence, numerous attributes for the overall evaluation process need to be defined. The authors outline a new hybrid multi-criteria decision making (hereinafter referred to as MCDM) model combining existing Delphi fuzzy techniques in order to help when decision making. This model was designed to tide over vagueness and various incoherent situations that may occur during the evaluation process. The model was applied to the terminal location in the city of Belgrade. This approach, however, does not tackle the comprehensive design of the terminal elements and their arrangement (compared to our research study), it only determines the specific terminal location in a certain region.

The methodology for locating and designing intermodal transport terminals in Croatia is elaborated in literature [12]. The authors rely on the selection of relevant intermodal terminal qualitative criteria (indicators), such as: Flexibility, safety, reliability, time, and spatial availability, etc. Following these criteria, as well as in accordance with the European transport policy, specific localization criteria set was defined and then assessed when implementing the Analytic Hierarchy Process (hereinafter referred to as AHP). The article outcomes emphasize the fact that the commodity flows' aspect reaches the most substantial effect on the terminal place choice.

On the contrary, Lin et al. [10] point to a mathematical solution of locational problems. It presents and evaluates multiple mathematical models, investigated by others, such as $[8,9,11,13]$, where their significant complexity and time-consuming character in terms of intermodal transport terminals' location selection are described. The purpose of the article is to create a new approach model enabling rapid results' retrieval. This study, nonetheless, does not take into account the inputs into the proposed model; it only addresses the desired attributes' quantification process itself.

The design of intermodal transport terminal elements, especially certain handling equipment, is addressed in the case study [18]. The authors state that, due to the significant amount of input data, it is necessary to use the specific multi-criteria decision making methods. In their paper, a novel hybrid model that combines the fuzzy stepwise weight assessment ratio analysis, as well as the fuzzy best-worst method, is developed. The model defined is applied to tackle a case study of selecting adequate handling equipment for the planned intermodal transport terminal in Belgrade. The reach stacker is selected to be the most fitting handling equipment, since it suits best the planned terminal in existing conditions and in relation to the predefined criteria. By presenting this study, the authors demonstrated justification for using chosen MCDM tools to deal with these sorts of problems, as well as applicability of the suggested model.

The previous procedure can be regarded as an alternative to the methodology designed in the article presented by us.

The topic of suggesting intermodal transport terminal elements and stipulating the appropriate type of handling equipment in logistics sites has not been sufficiently explored and analyzed. Even the last described manuscript is relatively new. This proves and highlights the topicality of the investigated subject and the fact that there is still space for further research in this field.

Unlike the aforementioned publications, the presented manuscript analyzes a specific location in which the need to operate the particular intermodal transport terminal has emerged due to the interest of particular customers, and points to options of applying the mathematical methods when building or revitalizing a defined transport-logistics node (intermodal transport terminal Nemanice). A new approach to the examined subject lies in the design of special handling devices in the intermodal transport terminal with respect to its operational-economic efficiency. The authors are aware of the importance and sustainability of such an operation, which is to be ensured only by the permanent competitiveness of the terminal. In other words, the terminal needs to provide its services at attractive prices, which are adjusted with regard to the terminal's operating costs. Hence, it is the specific types 
of mathematical methods that are used to choose the appropriate variant of handling equipment. The authors have not identified this view of the intermodal transport terminal design in any of the analyzed literature.

\section{Description of the Existing State of Intermodal Transport in the Czech Republic}

The development of unaccompanied intermodal transport (road-railway), carried out in the Czech Republic, has been very favorable for a long time. Growing importance of intermodal transport can be documented by its ever-increasing share not only in total freight transport (i.e., road, railway, inland waterway, air, and pipeline) but mainly in railway freight transport. According to the data [19], the share of intermodal transport in total freight transport (depending on transported tons) reached 2.45 percent, and in railway freight transport, it was almost up to 14.5 percent. In intermodal transport, containers are mainly used, wherein the number of full containers being transported has been continuously increasing. Nevertheless, it is not possible to unambiguously distinguish the maritime (ISO 1) and inland containers according to the statistical data, nor whether it is marine (intercontinental) or inland (continental) navigation [20]. In 2017, containers accounted for 93.4 percent, swap bodies for 1.8 percent, and road semi-trailers for 4.8 percent out of the total number of full intermodal transport units. The decisive share of full containers is represented by their carriage from/to seaports (so-called marine navigation) with previous or subsequent marine navigation [21-23].

The quantity of intermodal road semi-trailers has also been gradually increasing, with 40.8 thousand road trailers being transported in 2017. In contrast to the previous, the number of carried swap bodies is relatively insignificant and varies to a great extent in each year-only 15.6 thousand in 2017, of which approximately half are in transit [22,24].

According to the data from the Ministry of Transport of the Czech Republic [25], of 15 publicly accessible transport terminals were in operation in 2019. List of these objects, in which intermodal transport is currently carried out, their operators and the annual transshipment volume are summarized in Table 1. Nowadays, the Metrans company is being the fastest growing operator of intermodal transport, which operates its terminals even in Slovakia, Hungary, as well as in Austria, and in 2017, it expanded to the Polish market as well [26-31].

Table 1. Intermodal Transport Terminals in the Czech Republic (November 2019).

\begin{tabular}{ccc}
\hline Location & Operator & Volume of Transshipment/Year \\
\hline Brno & Terminal Brno & 15,000 TEU \\
Česká Třebová & Metrans & 850,000 TEU \\
Lovosice & ČD Duss Terminal & 53,000 TEU \\
Mělník & České př́stavy & 150,000 TEU \\
Nýřany & Metrans & 70,000 TEU \\
Paskov & AWT & 54,000 TEU \\
Praha-Uhříněves & Metrans & $1,013,200$ TEU \\
Př́rov & RCO-CSKD & 18,000 TEU \\
Šenov & Metrans & 90,000 TEU \\
Ústí nad Labem & Metrans & 12,500 TEU \\
Zlín & Metrans & 250,000 TEU \\
\hline
\end{tabular}

Source: Authors, based on [25]. Explanatory notes: TEU: Twenty-foot equivalent unit.

Figure 1 depicts the geographical distribution of all transport terminals in the Czech Republic, including those focusing on transshipment within other transport modes rather than intermodal transport, where an uneven coverage on the network is evident. The highest concentration of these objects is found in the Ústí nad Labem region, in which up to six terminals are currently in operation. Conversely, the South Bohemian region and the Vysočina region do not dispose of any of such transshipment station. 


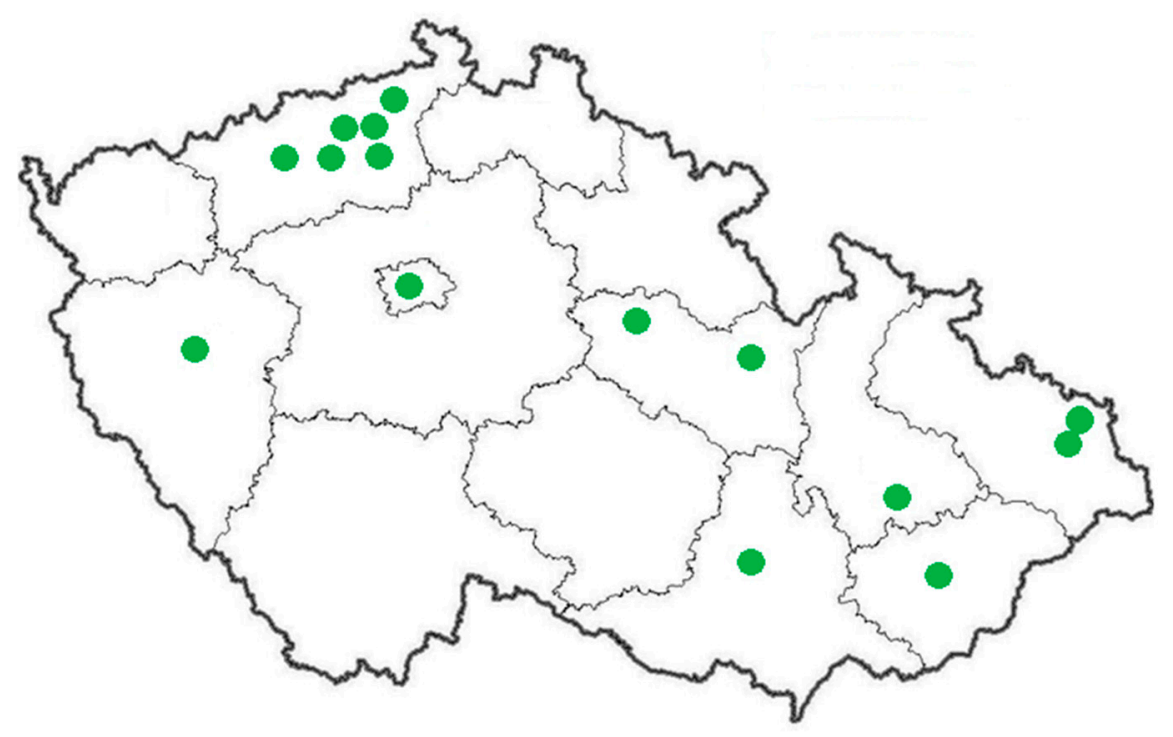

Figure 1. Location of transshipment stations in the Czech Republic. Source: Authors. Explanatory notes: transshipment station in operation.

As for the investigated city of České Budějovice, the closest terminals are located in Prague-Uhříněves (approx. $140 \mathrm{~km}$ ) and Plzeň-Nýřany (approx. $150 \mathrm{~km}$ ). In terms of coverage of the South Bohemia region being examined, the intention to renew operation of the currently defunct transshipment station Nemanice nearby the county city of České Budějovice is, thereby, logical and reasonable [32].

\section{A Case Study: Intermodal Transport Terminal Nemanice}

Container transshipment facility located in Nemanice (part of the city of České Budějovice) has a relatively long history, however, like other transshipment stations in the country, with fluctuating success. For the first time, this facility was put into operation in 1979, when the activities of the back then national container transport operator ČSKD INTRANS were moved to this object from a temporary station in České Budějovice. In 1991, the first stage of the Nemanice facility complex rebuilding process was carried out, and next year, the second construction stage followed. During the reconstruction, the areas of the transshipment station were modified, and several rubber-tyred gantry cranes were replaced with a single rail mounted gantry crane. Czech Railways company was the owner of this terminal and the ČSKD INTRANS company was its tenant back then. In addition to containers' transshipment, ČSKD INTRANS started to operate the Ro-La transport line to Villach in 1993. This system of carriage of road freight vehicles and vehicle combinations with crews was terminated in 1999 due to the lack of interest. Thereby, the transshipment hub Nemanice operation was dampened, and in March 2000, its operation was completely terminated [33,34].

Revitalization of the Nemanice terminal is basically a new project without previous experience. Since the termination of the original industrial site in 2000, intermodal transport conditions have changed radically. No past data can be relied upon, inasmuch as potential customers' structure has changed in the region. Terminal elements, whose parameters depend on planned performance, are dealt with on a heuristic principle, for example, in [35].

As far as the volume of transportation flows is concerned, an expert estimate of the Metrans company is taken into account. Based on the knowledge of the intermodal transport market and the industrial coverage of individual regions, the company estimated the future transport potential of the intermodal transport terminal Nemanice in the amount of $60 \%-70 \%$ of the handling operations compared to the intermodal transport terminal Nýřany (Metrans company has already expressed an interest in revitalizing and reopening the Nemanice transshipment station). This terminal reported 
performance of 70,734 TEUs in 2016. Thereby, according to the company's estimate, the Nemanice terminal transport potential could be up to 42,000-49,000 TEU/year (an average of 46,000 TEU/year).

Amount of handling operations, nevertheless, depends on the used intermodal transport unit (hereinafter referred to as ITU). Transport units being considered are represented by the most utilized types of ITUs, large containers ISO 1C (20-foot maritime container with a length of 6,058 mm), ISO 1A (40-foot maritime container with a length of 12,192 mm), ISO 1E (45-foot maritime container with a length of 13,716 mm), swap bodies (detachable superstructure of a lorry loading area, most often with a length of 7,150 mm, C series) as well as intermodal road semi-trailers. To converse the total performance volume in TEUs to ITUs, the individual ITUs' size data in TEUs, listed in the following Table 2, and the estimated shares in the total number of ITUs handled in the terminal per year are used.

Table 2. Size of used intermodal transport units (ITUs) in TEUs and their shares in the total number of ITUs.

\begin{tabular}{ccc}
\hline Intermodal Transport Unit & TEU & Share in the ITUs \\
\hline ISO 1C & 1 & $2 / 6$ \\
ISO 1A, or ISO 1E & 2 & $2 / 6$ \\
Intermodal road semi-trailer & 2 & $1 / 6$ \\
Swap body of the C series & 1.5 & $1 / 6$ \\
\hline
\end{tabular}

Source: Authors.

Ergo, the sum of volumes of each ITU converted to TEU should be of 46,000 TEU (see Equation (1)).

$$
\begin{gathered}
1 \text { TEU } * \frac{2 x}{6}+2 \text { TEU } * \frac{2 x}{6}+2 \text { TEU } * \frac{x}{6}+1.5 \text { TEU } * \frac{x}{6}=46,000 \text { TEU } \\
2 x+4 x+2 x+1.5 x=276,000 \text { TEU } \\
x=29,052 \text { ITU } / \text { year }
\end{gathered}
$$

According to the estimated shares of individual types of ITUs in the total volume (based on the calculation above), the reloading rate of 29,052 ITUs per year is expected. Table 3 shows the estimated amount of individual reloaded ITU types in TEU per year.

Table 3. Estimated annual volume of the transport performance in TEU.

\begin{tabular}{ccc}
\hline Intermodal Transport Unit & pcs/Year & TEU/Year \\
\hline ISO 1C & 9684 & 9684 \\
ISO 1A, or ISO 1E & 9684 & 19,368 \\
Intermodal road semi-trailer & 4842 & 9684 \\
Swap body of the C series & 4842 & 7263 \\
\hline \multicolumn{2}{c}{ Source: Authors, Explanatory notes: pcs, pieces. }
\end{tabular}

Apparently, the number of handled ISO 1A or ISO 1E is by far the highest, i.e., 19,368 per year, and the quantity of reloaded swap body of the $C$ series is the lowest.

The technical quality level of the Nemanice transshipment station elements, their current state and spatial disposition are far from the required standards for the intermodal transport terminals at the European scale. The primary impetus to address the revitalization project of the Nemanice terminal is to support the continuous growth of intermodal transport volumes in the Czech Republic (especially the demand of intermodal transport operators) as well as the absence of an operational terminal in the South Bohemian region.

The specific intermodal transport terminal elements being demanded are suggested in the following Sections 4.1-4.4. 


\subsection{Connection to the Transport Network}

Railway line no. 704 (České Budějovice-Benešov u Prahy) is regarded as a part of IV. corridor of the TEN-T network (stands for Trans-European Transport Network) and is included in the network of railways important for international intermodal transport of the AGTC agreement. The city of České Budějovice, part of which is the urban part of Nemanice, is listed in the AGTC agreement as a terminal site being of great importance for international intermodal transport. Proposal for connecting the intermodal transport terminal Nemanice to the transport network has been elaborated based on the current state analysis of road and railway networks, or their future development. Connection of the Nemanice terminal to the railway network is given by the proximity of the railway track switch Nemanice.

To this end, part of the proposal lies in a change of a way of the terminal handling tracks' connection as well as a change in Nemanice II railway track switch. The proposal to change the railway switch is to abolish the handling tracks, which are currently unused. The acquired area would be incorporated into the terminal site. The connection of the terminal handling tracks to the railway network itself is designed in the opposite direction, compared to the present one, from the station Hluboká nad Vltavou through the new track no. 203a. This change in connection is designed in order to facilitate the terminal operation while loading and unloading without significant limitation of other transport operations on railway line 709 České Budějovice-Plzeň main station and operation on the nearby frequented road no. III/10578.

Connection of the Nemanice transshipment station to the network of public roads is now complicated due to the absence of traffic bypasses of the northern edge of České Budějovice. The priority solution to connect the terminal is solved by downhills from the planned bypass of the Northern Tangent, which means the interconnection of the road no. I/20 with the D3 motorway. Since this planned construction has not assigned the final decision regarding the environmental impact assessment (EIA), according to the Directorate of Roads and Motorways (Czech Republic), its implementation is still a matter of at least seven years. The second solution is to connect the terminal premises to the prepared bypass of the North Connection, which is scheduled to be put into operation due 2022. These days, negotiations have been taken place to modify the original bypass project, which did not take into account the Nemanice transshipment station connection [36,37].

\subsection{Handling Equipment}

The choice of types and the quantity of handling devices depends on the ability of the terminal to promptly, efficiently, and without unnecessary handling operations to handle road carriers and load ITUs on wagons. Requirements for handling times are defined by the AGTC agreement, the maximum duration of road vehicle downtime in an intermodal transport terminal is specified to 20 minutes, and the marginal time from taking over the shipment up to the train departure should not exceed one hour.

In principle, intermodal transport terminal can be equipped in three ways:

- reach stackers;

- gantry cranes on rails or tires;

- a combination of both.

Common requirements for stackers and gantry cranes include a loading capacity (payload) of 42 tons and a spreader with collets for handling all ITUs being considered. The desired number of handling mechanisms depends on the quantity of handling operations executed per day, and the actual working cycle time-period. Handling time also depends on the size of the handling areas and the length of the handling equipment crossings. The overall need for handling equipment can be 
determined according to the general equation (see Equations (2) and (3)) to quantify the operational need for cyclically-working handling devices as follows [38]:

$$
\begin{gathered}
n_{c}^{I T T}=\frac{N_{I T U} * t_{I T U}}{3600 *\left(T_{p}-T_{p p}\right) * G_{d} * \alpha_{p v}} *\left(1+\frac{r}{100}\right), \quad[p c s] \\
N_{I T U}=Q * k_{d} * k_{v o}, \quad[p c s]
\end{gathered}
$$

where $n_{\mathcal{C}}{ }^{I T T}$ is operational need for handling equipment [pcs], $N_{I T U}$ is the number of intermodal transport units [pcs], $Q$ is daily handling need [ITU/day], $k_{d}$ is coefficient of double handling $=1.4, k_{v o}$ is coefficient of ancillary handling $=1.2, t_{I T U}$ is the average time of one operation with ITU $[s], T_{p}$ is working time-period [h] (morning + afternoon shift: $2 \times 8$ hours), $T_{p p}$ is breaks at work [h] $(2 \times 30 \mathrm{~min})$, preparatory and weaning works $(15+15 \mathrm{~min}), G_{d}$ is the average amount of batch per one working cycle [pcs], $\alpha_{p v}$ is coefficient of operational utilization $=0.3, r$ is operational reserve $10 \%$.

\subsection{Handling Tracks}

The number and length of terminal railway handling tracks depend on the expected transport performance. However, a certain reserve is to be taken into account in case of performance increases. The total useful length of the handling track required to handle the daily load is calculated at 1066.5 meters for Sggmrss wagons intended to be deployed within intermodal transport (based on the formula specified in [5,39]). AGTC agreement requires a minimum length of such tracks at $750 \mathrm{~m}$ for the newly constructed terminals. In the intermodal transport terminal Nemanice, two reloading tracks are suggested to be built, each with a useful length of $750 \mathrm{~m}$.

\subsection{Spatial Layout of the Terminal}

To handle a given amount of load, it is necessary to properly dimension the terminal spatial elements, such as the number and length of handling tracks, the size of storage and depositing areas, both in relation to the determined terminal operation technology by railway and road vehicles. The stationary method was selected in terms of operation technology in the terminal by railway transport. As for the operation technology by road vehicles, for a terminal of a similar size, a single-circuit transport system is appropriate, with transport units being loaded and unloaded from vehicles directly on the transshipment area [40].

The size of storage and depositing areas of the transshipment station depends on the planned transportation volume of the ITUs being handled, their type, and stackability. ISO containers are estimated to be $2 / 3$ of the transportation volume, but due to stackability, they need a depositing area comparable to road semi-trailers. For short-term storage of ISO containers, an area of at least $717 \mathrm{~m}^{2}$ is needed (according to the formula specified in [4]). For short-term parking of road semi-trailers, an area of at least $743 \mathrm{~m}^{2}$ has to be reserved, and an area of at least $557 \mathrm{~m}^{2}$ for swap bodies' storage. The design also includes the areas necessary for the terminal operation itself, area intended to store transport units during dangerous goods transportation, repair, and maintenance area, as well as parking area. The total area of the terminal is of $45,000 \mathrm{~m}^{2}$.

\section{Solution and Results}

As mentioned, the revitalization proposal consists of a variant solution of equipage and subsequent alignment of the terminal elements. The terminal's equipment and layout will have a consequent effect on the overall work technology and the terminal's operational and economic indicators. Numerous exact mathematical methods can be applied to select the most appropriate variant of the terminal layout. These methods operate with multiple factors (criteria) affecting the final selection.

The proposed equipment options for the terminal differ in the amount of investments required as well. As far as the economic comparison is concerned, the cost items varying in each scenario will 
be taken into account. To build the paved surfaces for heavy freight transport, the charge of $60 € / \mathrm{m}^{2}$ is calculated.

\subsection{Scenario No. 1-Reach Stackers}

The spatial disposition of the terminal in this scenario is illustrated in Figure 2. All areas are paved and adapted for the movement of stackers. Such a paved surface has dimensions of $750 \times 55$ meters.

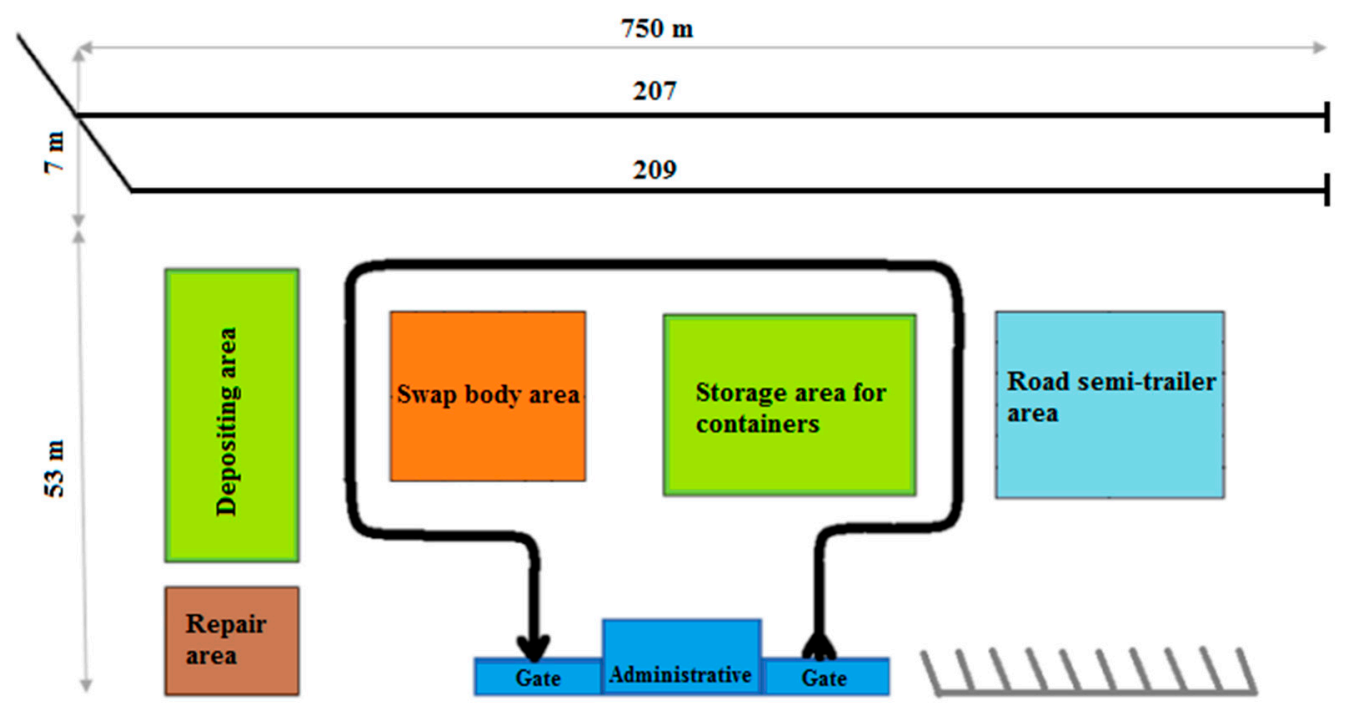

Figure 2. Scenario no. 1 scheme with reach stackers. Source: Authors.

Acquisition cost regarding scenario no. 1 is shown in Table 4.

Table 4. Acquisition cost for scenario no. 1.

\begin{tabular}{cccc}
\hline Cost Item & Unit Price & Terminal Demand & Cost per Item in $€$ \\
\hline Reach stacker & $450,000 €$ & $4 \mathrm{pcs}$ & $1,800,000$ \\
Paved surface & $60 € / \mathrm{m}^{2}$ & $39,750 \mathrm{~m}^{2}$ & $2,385,000$ \\
\hline & Total: & $\mathbf{4 , 1 8 5 , 0 0 0}$ \\
\hline
\end{tabular}

Source: Authors.

The overall need for handling equipment in the terminal is covered by four reach stackers in two eight-hour shifts. Personal need for one reach stacker and one shift is ensured by two employees. The operational cost per one hour is of $€ 13$. Maintenance cost has been recalculated to 1000 hours from the data as follows: Replacement of rear tires ( 2 pcs) each of 2500 hours, replacement of front tires (4 pcs) each of 5,000 hours. The cost of one tire is $€ 3600$. Price and cost data were provided by the intermodal transport handling equipment manufacturer.

The following Table 5 summarizes all the data related to scenario no. 1 .

Table 5. Criteria and their values for scenario no. 1.

\begin{tabular}{ccc}
\hline Criterion & Reach Stacker & Terminal in Total \\
\hline $\mathrm{C}_{1}:$ Acquisition cost $(€)$ & 450,000 & $4,185,000$ \\
$\mathrm{C}_{2}:$ Operational cost $(€ / \mathrm{h})$ & 13 & 52 \\
$\mathrm{C}_{3}:$ Maintenance cost $(€ / 1000 \mathrm{~h})$ & 5760 & 23,040 \\
$\mathrm{C}_{4}:$ Average working cycle time $(\mathrm{s})$ & 225 & 225 \\
$\mathrm{C}_{5}:$ Personal demand per 2 shifts $(\mathrm{pcs})$ & 4 & 16 \\
\hline
\end{tabular}


The data (criteria and their values) listed in Table 5 is needed for further calculations regarding scenario no. 1 when using the particular multi-criteria decision analysis methods [16,41].

\subsection{Scenario No. 2-Rail Mounted Gantry Cranes}

The terminal spatial layout proposal of scenario no. 2 is depicted in Figure 3. In this variant, most of the storage areas are within reach of the rail-mounted gantry cranes (RMG), the rest of the area is formed by the paved surface for the movement of the reach stacker and road vehicles. The paved surface has dimensions of $750 \times 40$ meters.

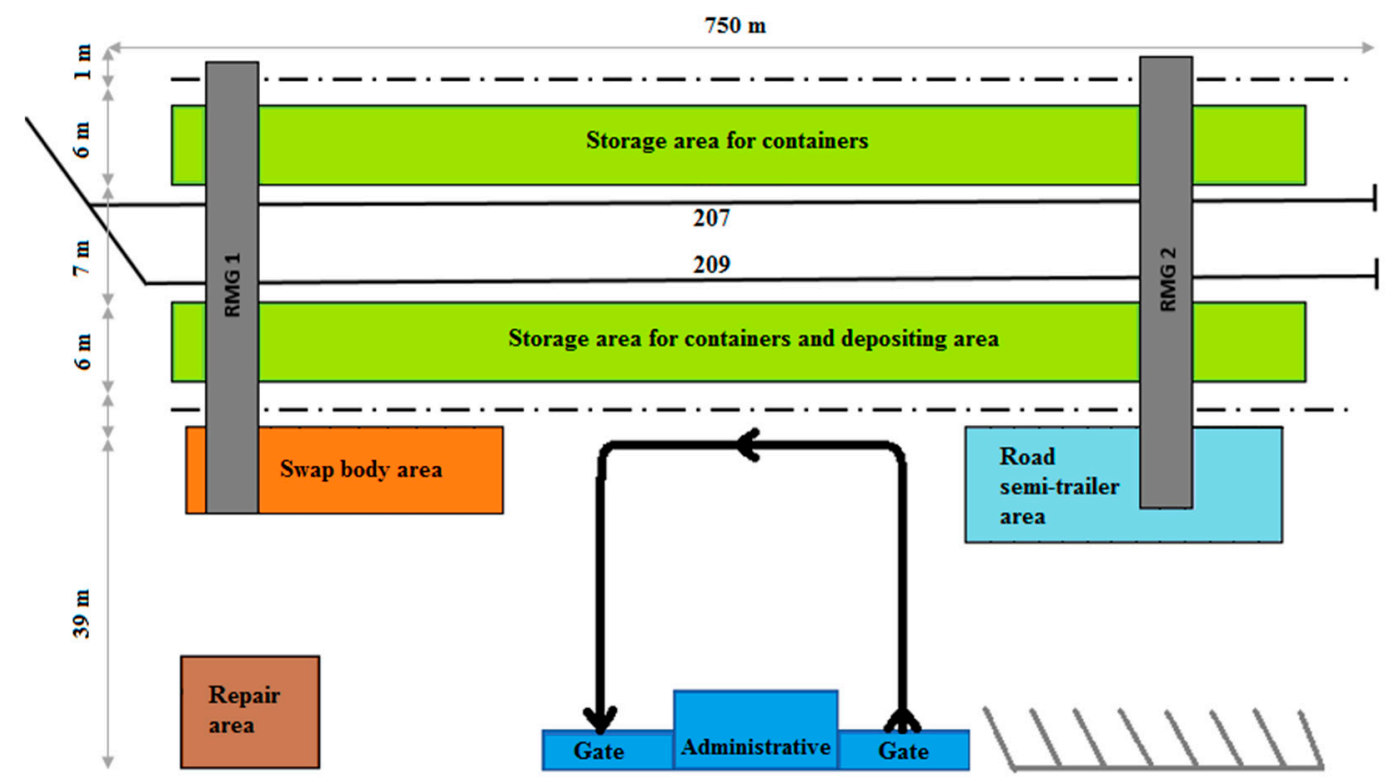

Figure 3. Scenario no. 2 scheme with rail-mounted gantry cranes. Source: Authors.

Acquisition cost regarding scenario no. 2 is presented in Table 6.

Table 6. Acquisition cost for scenario no. 2.

\begin{tabular}{cccc}
\hline Cost Item & Unit Price & Terminal Demand & Cost per Item in $\boldsymbol{\epsilon}$ \\
\hline RMG crane & $3,500,000 €$ & $2 \mathrm{pcs}$ & $7,000,000$ \\
Reach stacker & $450,000 €$ & $1 \mathrm{pcs}$ & 450,000 \\
Rail track & $2,855,000 € / 1 \mathrm{~km}$ & $700 \mathrm{~m}$ & $2,000,000$ \\
Paved surface & $60 € / \mathrm{m}^{2}$ & $29,250 \mathrm{~m}^{2}$ & $2,385,000$ \\
\hline & & Total: & $\mathbf{1 1 , 2 0 5 , 0 0 0}$ \\
\hline
\end{tabular}

Source: Authors.

In the event of equipping the terminal with RMG cranes, as the main handling devices, another additional handling mechanism must be available in the site [42]. As for the intermodal transport terminal Nemanice, one ancillary reach stacker is taken into consideration. In regard to the personal demand for two RMG cranes and one stacker, four employees per shift are necessary. Operational cost is $€ 12$ per hour of operation, maintenance cost is $€ 7700 / 1,000$ hours of operation. The acquisition cost of cranes still needs to take into account the cost of the crane rail track, which is of $€ 2,000,000$ for $700 \mathrm{~m}$ long track.

Table 7 summarizes all the data related to the proposed scenario no. 2 .

All this data is also needed for further calculations concerning this variant when using the specific mathematical methods. 
Table 7. Criteria and their values for scenario no. 2.

\begin{tabular}{ccc}
\hline Criterion & RMG Crane & Terminal in Total \\
\hline $\mathrm{C}_{1}:$ Acquisition cost $(€)$ & $3,500,000$ & $11,205,000$ \\
$\mathrm{C}_{2}:$ Operational cost $(€ / \mathrm{h})$ & 12 & 37 \\
$\mathrm{C}_{3}:$ Maintenance cost $(€ / 1000 \mathrm{~h})$ & 7700 & 26,920 \\
$\mathrm{C}_{4}:$ Average working cycle time $(\mathrm{s})$ & 131 & 131 \\
$\mathrm{C}_{5}:$ Personal demand per 2 shifts $(\mathrm{pcs})$ & 2 & 8 \\
\hline
\end{tabular}

Source: Authors.

\subsection{Scenario No. 3-Rubber-Tyred Gantry Cranes}

The design of the terminal scenario no. 3 is shown in Figure 4. Unlike scenario no. 2, this variant has more paved surfaces due to the rail track surfaces for the movement of cranes on tires.

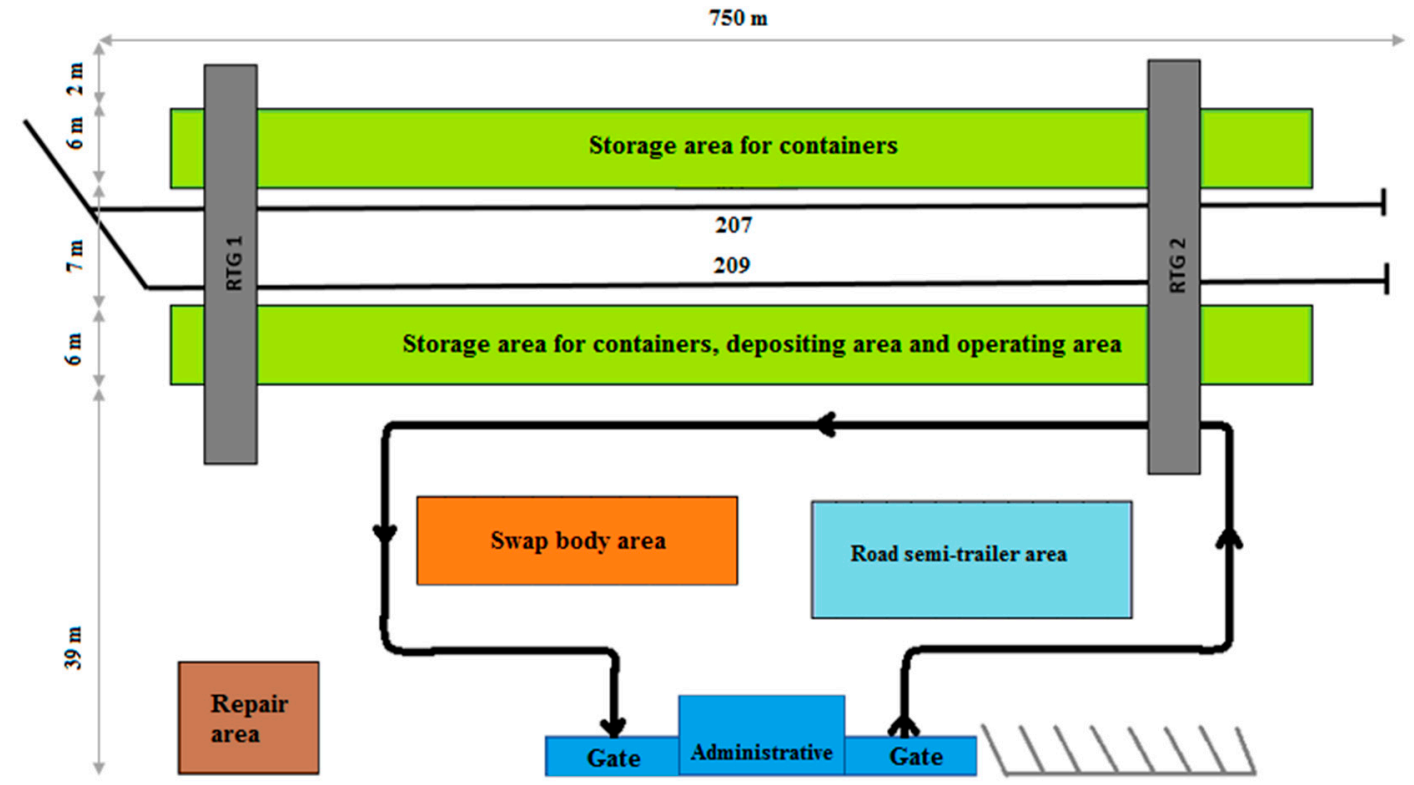

Figure 4. Scenario no. 3 scheme with rubber-tyred gantry cranes. Source: Authors.

Acquisition cost regarding scenario no. 3 is summarized in Table 8.

Table 8. Acquisition cost for scenario no. 3 .

\begin{tabular}{cccc}
\hline Cost Item & Unit Price & Terminal Demand & Cost per Item in $\boldsymbol{\epsilon}$ \\
\hline RTG crane & $2,000,000 €$ & 2 pcs & $4,000,000$ \\
Reach stacker & $450,000 €$ & $2 \mathrm{pcs}$ & 900,000 \\
Paved surface & $60 € / \mathrm{m}^{2}$ & $30,750 \mathrm{~m}^{2}$ & $1,845,000$ \\
\hline & & Total: & $\mathbf{6 , 7 4 5 , 0 0 0}$ \\
\hline
\end{tabular}

Source: Authors.

Two rubber-tyred gantry cranes are needed to cover the handling needs of the terminal. As for the additional handling device, two reach stackers are taken into account for the operation. Operational costs are $€ 16$ per hour of operation. Maintenance cost has been recalculated to 1000 hours from the data as follows: Replacement of eight tires of each RTG crane after 25,000 hours. The cost of purchasing one tyre is $€ 7000$ [43]. In this case, a personal need for two staff to operate the cranes and four staff to operate the stackers in one shift is necessary.

The following Table 9 summarizes all the data regarding scenario no. 3 . 
Table 9. Criteria and their values for scenario no. 3.

\begin{tabular}{ccc}
\hline Criterion & RTG Crane & Terminal in Total \\
\hline $\mathrm{C}_{1}$ : Acquisition cost $(€)$ & $2,000,000$ & $6,745,000$ \\
$\mathrm{C}_{2}$ : Operational cost $(€ / \mathrm{h})$ & 14 & 54 \\
$\mathrm{C}_{3}:$ Maintenance cost $(€ / 1000 \mathrm{~h})$ & 8300 & 28,120 \\
$\mathrm{C}_{4}:$ Average working cycle time $(\mathrm{s})$ & 172 & 172 \\
$\mathrm{C}_{5}:$ Personal demand per 2 shifts $(\mathrm{pcs})$ & 2 & 12 \\
\hline
\end{tabular}

Source: Authors.

And again, the information (criteria and their values) listed in Table 9 is necessary for further calculations regarding scenario no. 3 when using the particular multi-criteria decision analysis methods.

\subsection{Determination of the Weights of Criteria}

Determining the weights of criteria is generally a subjective process. Nonetheless, it can be objectivized by using multi-criteria decision analysis methods.

In our case, the Saaty method was applied to determine the criteria weights [41,44]. This method was chosen given the fact that no information is available for the ordinal alignment of criteria from the most important. However, it is possible to conduct a quantitative pairwise comparison of criteria based on cardinal information. In contrast to a simple pairwise comparison, the Saaty method uses quantification of such a comparison. The Saaty method has also defined the scale of values in terms of pairwise comparison [17].

To this end, the Saaty matrix is compiled in the following Table 10.

Table 10. Saaty matrix.

\begin{tabular}{cccccccc}
\hline & $\mathbf{C}_{\mathbf{1}}$ & $\mathbf{C}_{\mathbf{2}}$ & $\mathbf{C}_{\mathbf{3}}$ & $\mathbf{C}_{\mathbf{4}}$ & $\mathbf{C}_{\mathbf{5}}$ & $\mathbf{b}_{\mathbf{i}}$ & $\mathbf{v}_{\mathbf{i}}$ \\
\hline $\mathbf{C}_{\mathbf{1}}$ & 1 & $1 / 3$ & 1 & $1 / 3$ & $1 / 3$ & 0.52 & 0.09 \\
$\mathbf{C}_{\mathbf{2}}$ & 3 & 1 & 5 & 1 & 1 & 1.72 & 0.29 \\
$\mathbf{C}_{\mathbf{3}}$ & 1 & $1 / 5$ & 1 & $1 / 3$ & $1 / 3$ & 0.47 & 0.08 \\
$\mathbf{C}_{\mathbf{4}}$ & 3 & 1 & 3 & 1 & 1 & 1.55 & 0.27 \\
$\mathbf{C}_{5}$ & 3 & 1 & 3 & 1 & 1 & 1.55 & 0.27 \\
\hline $\boldsymbol{\Sigma}$ & & & & 5.81 & 1.00 \\
\hline \multicolumn{2}{l}{ Source: Authors. Where: $b_{i}$, line geometric mean; $v_{i}$, weight of criterion, while $v_{i}=\frac{b_{i}}{\sum_{1}^{n} b_{i}}}$.
\end{tabular}

In our case, the process of determination of the weights of criteria was carried out as follows [16,41]:

(1) First of all, the relation among each criterion pair being compared needs to be defined, wherein the degree of preference is quantified within a point scope of 1-9. All input values related to the criteria weights can be acquired by conducting a survey, interviewing (experts' opinion), etc. Undeniably, identification of a proper set of decision making criteria in association with an intermodal transport terminal operation is considered to be a strongly specific process. That is why multiple experts who intensively deal with intermodal transport issues were requested to express their opinions (i.e., input preference values among each criterion pair being compared) in our study. To provide for as high objectivity as possible, ten experts focused on the investigated field of research were requested to lay down preference values among each criterion pair. Namely, they were assigned by members of the working group, organized in the city of České Budějovice in 2015, where the topics on the potential revitalization of the Nemanice transshipment station were discussed.

The following Table 11 gives a brief description of the expert representatives who participated in the task related to identifying the criteria set as well as rating their weights.

(2) As far as the Saaty matrix items are concerned, individual preference values assigned by all the decision-makers were specified, and thereafter, arithmetic mean out of all values of each partial matrix was quantified. 
(3) Subsequently, Saaty matrix items were utilized for the following calculations (i.e., to quantify line geometric means, to quantify the final vector of criterion weights, see Table 10).

Table 11. The list of experts participating in the investigation.

\begin{tabular}{ccc}
\hline Name of the Organization & Scope of Business & Date of Investigation \\
\hline Metrans & Intermodal transport operator & February 2, 2015 \\
Česmad Bohemia & Road carriers' association & February 2, 2015 \\
Bohemiakombi & Intermodal transport operator & February 2, 2015 \\
ČD Cargo & National railway carrier & February 2, 2015 \\
Railway Administration & Railway Infrastructure Manager, Czechia & April 25, 2015 \\
ČD DUSS & Terminal operator & March 18, 2015 \\
Czech Logistics Association & Logistics non-profit organization & February 2, 2015
\end{tabular}

\subsection{Application of the TOPSIS Method to Define the Final Variant Ranking}

The Technique for Order Preference by Similarity to Ideal Solution (referred to as TOPSIS method) is based on the selection of the variant closest to the ideal variant and furthest from the basal variant. It requires cardinal information about the criteria preferences that is given by the Saaty method [45].

The maximization nature is preferred, and therefore all the minimization criteria must be converted into the maximization nature. The first step of the TOPSIS method comes from the values listed in Table 12 (values already converted into the maximization criteria), while maintaining the weights determined by the Saaty method. A maximization process to convert all the values into maximization nature is performed based on the Equation (4):

$$
y_{i j m a x}=h_{j \min }-y_{i j m i n}
$$

where $y_{i j m a x}$ is the defined value of $i$-th variant by $j$-th criterion with a maximization nature, $h_{j m i n}$ represents the highest value of the $j$-th criterion with a minimization nature, $y_{i j m i n}$ is the value of $i$-th variant by $j$-th criterion with a minimization nature.

Table 12. Initial criteria matrix, Technique for Order Preference by Similarity to Ideal Solution (TOPSIS) method.

\begin{tabular}{cccccc}
\hline & $\mathrm{C}_{\mathbf{1}}$ & $\mathrm{C}_{\mathbf{2}}$ & $\mathrm{C}_{\mathbf{3}}$ & $\mathrm{C}_{4}$ & $\mathrm{C}_{\mathbf{5}}$ \\
\hline $\mathbf{V}_{\mathbf{1}}$ & 7020 & 7 & 3880 & 0 & 0 \\
$\mathbf{V}_{\mathbf{2}}$ & 0 & 22 & 0 & 94 & 8 \\
$\mathbf{V}_{\mathbf{3}}$ & 4460 & 0 & 10,920 & 53 & 4 \\
\hline
\end{tabular}

Source: Authors.

The next step is to compile the normalized criteria matrix $R=\left(r_{i j}\right)$ (see Table 13). The matrix $R$ is compiled according to the Equation (5) [45]:

$$
r_{i j}=\frac{y_{i j}}{\sqrt{\sum_{i=1}^{m} y_{i j}^{2}}} ; \mathrm{i}=1,2, \ldots, m ; j=1,2, \ldots, n
$$

where $r_{i j}$ is the normalized value of the particular variant by each criterion, $y_{i j}$ is the defined value of $i$-th variant by $j$-th criterion. 
Table 13. Normalized criteria matrix, TOPSIS method.

\begin{tabular}{cccccc}
\hline & $\mathbf{C}_{\mathbf{1}}$ & $\mathbf{C}_{\mathbf{2}}$ & $\mathrm{C}_{\mathbf{3}}$ & $\mathrm{C}_{\mathbf{4}}$ & $\mathrm{C}_{\mathbf{5}}$ \\
\hline $\mathbf{V}_{\mathbf{1}}$ & 0.84 & 0.29 & 0.33 & 0 & 0 \\
$\mathbf{V}_{\mathbf{2}}$ & 0 & 0.95 & 0 & 0.87 & 0.89 \\
$\mathbf{V}_{\mathbf{3}}$ & 0.54 & 0 & 0.94 & 0.49 & 0.45 \\
\hline $\boldsymbol{v}_{i j}$ & 0.09 & 0.29 & 0.08 & 0.27 & 0.27 \\
\hline \multicolumn{7}{c}{ Source: Authors. }
\end{tabular}

In regard to the next step, the weighted normalized criteria matrix $Z=\left(z_{i j}\right)$ needs to be compiled by multiplying the normalized variant value by each criterion and the normalized weight of the relevant criterion (see Equation (6)), wherein the ideal variant $H$ and basal variant $D$ can be determined subsequently (see Table 14) [46,47].

$$
z_{i j}=v_{j} r_{i j},[-]
$$

where $v_{j}$ is relevant normalized weight of criterion, $r_{i j}$ is the normalized value of the particular variant by each criterion.

Table 14. Weighted normalized criteria matrix, TOPSIS method.

\begin{tabular}{cccccc}
\hline & $\mathrm{C}_{\mathbf{1}}$ & $\mathrm{C}_{\mathbf{2}}$ & $\mathrm{C}_{\mathbf{3}}$ & $\mathrm{C}_{\mathbf{4}}$ & $\mathrm{C}_{\mathbf{5}}$ \\
\hline $\mathbf{V}_{\mathbf{1}}$ & 0.08 & 0.09 & 0.03 & 0 & 0 \\
$\mathbf{V}_{\mathbf{2}}$ & 0 & 0.29 & 0 & 0.23 & 0.24 \\
$\mathbf{V}_{\mathbf{3}}$ & 0.05 & 0 & 0.08 & 0.13 & 0.12 \\
\hline $\mathrm{D}$ & 0 & 0 & 0 & 0 & 0 \\
\hline $\mathrm{H}$ & 0.08 & 0.29 & 0.08 & 0.23 & 0.24 \\
\hline
\end{tabular}

The next step is to calculate the deviation of each $\mathrm{Z}$ matrix value from the ideal $d_{i}{ }^{+}$variant (see Equation (7)) [48].

$$
d_{i}^{+}=\sqrt{\sum_{j=1}^{n}\left(z_{i j}-h_{j}\right)^{2}} ; \mathrm{i}=1,2, \ldots, m ; j=1,2, \ldots, n,[-]
$$

where $z_{i j}$ is the individual values of normalized criteria matrix $Z, h_{j}$ is the best (highest) value of the $j$-th criterion (ideal variant).

Analogously, the deviation of each $Z$ matrix value from the basal variant $d_{i}{ }^{-}$needs to be determined (see Equation (8)) [45].

$$
d_{i}^{-}=\sqrt{\sum_{j=1}^{n}\left(z_{i j}-d_{j}\right)^{2}} ; \mathrm{i}=1,2, \ldots, m ; j=1,2, \ldots, n,[-]
$$

where $d_{j}$ is the worst value of the $j$-th criterion (basal variant).

All the variants are then ordered depending on the values of the relative indicator $c_{i}$ and the variant ranking can be specified (see Table 15). This indicator is calculated as follows (see Equation (9)) [48]:

$$
c_{i}=\frac{d_{i}^{-}}{d_{i}^{+}+d_{i}^{-}} ; \mathrm{i}=1,2, \ldots, m,[-]
$$


Table 15. Final variant ranking, TOPSIS method.

\begin{tabular}{ccccc}
\hline & $d^{+}$ & $d^{-}$ & $c_{i j}$ & Ranking \\
\hline $\mathbf{V}_{\mathbf{1}}$ & 0.39 & 0.12 & 0.23 & 3. \\
$\mathbf{V}_{\mathbf{2}}$ & 0.11 & 0.44 & 0.80 & 1. \\
$\mathbf{V}_{\mathbf{3}}$ & 0.33 & 0.20 & 0.38 & 2. \\
\hline \multicolumn{5}{c}{ Source: Authors. }
\end{tabular}

\subsection{Application of the WSA Method to Define the Final Variant Ranking}

The Weighted Sum Approach (hereinafter referred to as WSA) is a method based on the evaluation of utility maximization that uses cardinal information on variants depending on each criterion $[49,50]$. The initial criteria matrix by the WSA method is the same as by the TOPSIS method (see Table 12). Moreover, the same values as previously are used to determine the weight of criteria (according to the Saaty method).

The next step of the WSA technique lies in specifying the best marginal values, i.e., the ideal $H$ variant as follows $\{7,020 ; 22 ; 10,920 ; 94 ; 8\}$ and the worst marginal values, i.e., the basal $D$ variant as follows $\{0 ; 0 ; 0 ; 0 ; 0\}$. Afterward, the matrix for each variant can be compiled, and also the partial utility function can be calculated. The partial utility of the $y_{i j}$ criterion is specified by Equation (10) [2,51].

$$
u_{i j}=\frac{y_{i j}-d_{j}}{h_{j}-d_{j}} ; \mathrm{i}=1,2, \ldots, m ; j=1,2, \ldots, n
$$

where $u_{i j}$ is the partial utility function of the value $y_{i j}, y_{i j}$ is the determined value of $i$-th variant by $j$-th criterion.

Modified criteria matrix by the WSA method, i.e., partial utility function $u_{i j}$ for all the variants is compiled in the following Table 16, even with indicating the weights of criteria $v_{i j}$ [52].

Table 16. Modified criteria matrix, Weighted Sum Approach (WSA) method.

\begin{tabular}{cccccc}
\hline & $\mathbf{C}_{\mathbf{1}}$ & $\mathrm{C}_{\mathbf{2}}$ & $\mathrm{C}_{\mathbf{3}}$ & $\mathbf{C}_{\mathbf{4}}$ & $\mathrm{C}_{\mathbf{5}}$ \\
\hline $\mathbf{V}_{\mathbf{1}}$ & 1 & 0.32 & 0.36 & 0 & 0 \\
$\mathbf{V}_{\mathbf{2}}$ & 0 & 1 & 0 & 1 & 1 \\
$\mathbf{V}_{\mathbf{3}}$ & 0.64 & 0 & 1 & 0.56 & 0.5 \\
\hline$v_{i j}$ & 0.09 & 0.29 & 0.08 & 0.27 & 0.27 \\
\hline \multicolumn{7}{c}{ Source: Authors. }
\end{tabular}

The final step of the WSA method is to calculate the aggregate utility function for each variant $u\left(V_{i}\right)$. The partial utility functions for all the variants must be, thus, multiplied by the relevant normalized weight of criterion $\left(v_{j}\right)$ by Equation (11), and eventually, the aggregate utility function for each variant can be calculated, and thereby the final variant ranking by the WSA technique is specified (see Table 17) [17,53].

$$
u\left(V_{i}\right)=\sum_{j=1}^{n} v_{j} u_{i j} ; \mathrm{i}=1,2, \ldots, m ; j=1,2, \ldots, n,[-]
$$

Table 17. Final variant ranking, WSA method.

\begin{tabular}{ccc}
\hline & Aggregate Utility Function & Ranking \\
\hline $\mathbf{V}_{\mathbf{1}}$ & 0.21 & 3. \\
$\mathbf{V}_{\mathbf{2}}$ & 0.84 & 1. \\
$\mathbf{V}_{\mathbf{3}}$ & 0.42 & 2. \\
\hline \multicolumn{2}{c}{}
\end{tabular}


The final comparison of individual multi-criteria decision analysis methods is performed in Table 18 as follows.

Table 18. The final comparison and determination of the best variant.

\begin{tabular}{ccccc}
\hline & TOPSIS Method & WSA Method & $\sum$ & Final Variant Ranking \\
\hline $\mathbf{V}_{\mathbf{1}}$ & 3. & 3. & 6 & 3. \\
$\mathbf{V}_{\mathbf{2}}$ & 1. & 1. & 2 & 1. \\
$\mathbf{V}_{\mathbf{3}}$ & 2. & 2. & 4 & 2. \\
\hline \multicolumn{4}{c}{ Source: Authors. }
\end{tabular}

In this particular comparison, methods applied represent the criteria being compared, and the ranking value of the method refers to the critical values. The final outcome (i.e., the most suitable scenario for the revitalization of the defunct intermodal transport terminal Nemanice) is determined based on the lowest value acquired by the sum of all the variant ranking values [54].

\section{Discussion}

The above specified scenarios can be compared based on various perspectives. Comparison by each criterion separately generates a different variant ranking, since each variant has its advantages and disadvantages. None of the given scenarios has a decisive disadvantage, in all the worst-case criteria, which would knock it out of comparison immediately [55].

The TOPSIS method was utilized to calculate the relative distance of variants from the basal, i.e., the least suitable theoretical option. Based on this analysis, the solution containing rail mounted gantry cranes was evaluated to be the most advantageous, closest to the ideal variant $H$ and the furthest from the basal variant $D$. As the second-best option, the scenario including the implementation of rubber-tyred gantry cranes was identified, and as the third in order, and thereby the least suitable option, the variant with stackers was assigned.

To compare findings with the TOPSIS method, multi-criteria analysis was also conducted by using the WSA method, in particular, to specify the option with the greatest utility function depending on the determined criteria [56,57]. This utility maximization method evaluated the usefulness of individual variants in the same order as the previous method:

- $\quad$ scenario no. 2 as the most appropriate solution;

- $\quad$ scenario no. 3 as the second-best option in order;

- scenario no. 1 would bring the smallest utility depending on the given criteria.

Hence, to revitalize the Nemanice transshipment station, based on the defined criteria and their preferences, the option consisting of an introduction of two rail-mounted gantry cranes and one reach stacker appears to be the most suitable [58].

The compiled procedure of designing the intermodal transport terminal elements and specifying the appropriate type of handling equipment is deemed by the authors to be an insight into possible scenarios. Compared to the methodology suggested in [18], it is different and the crucial distinction lies in the system modeling methods applied, scenarios of recommended modifications for handling equipment, as well as the procedure to identify the individual criteria and their weights. The methodology designed in [18] focuses on the criteria affecting the technological operation of the equipment, which has an impact on the overall flow of shipments through the terminal. These include, for example, handling device lift speed, its turning radii, acceleration, etc. On the contrary, the methodology drafted in this research study was consulted with leading practitioners directly involved in the operation of intermodal transport, as operators, carriers or transport infrastructure managers. The guideline proposed in this article is based to a greater extent on the economic criteria that are more preferred in real traffic. Furthermore, the presented methodology comprehensively addresses the topic of handling equipment and is based on determining the transport potential, from which the 
operational need of the equipment is quantified, and afterwards, in the third step, the very proposal of the types of equipment and variant comparison using specific exact methods are approached. The methodology suggested in [18] deals only with the last part, namely the design of a suitable type of equipment. From this point of view, our proposed methodology may be regarded as the benefit for further scientific-research knowledge, which can be further scientifically processed and extended. Of course, the authors take into account the fact that this is only one of the optional scenarios and do not avoid the discussion or opposition in association with other possible alternatives in the future.

The draft procedure can be implemented in practice under any circumstances, but it is inevitable to correctly and precisely define the inputs, above all the weights of criteria depending on the preferences of entities being participated. The methodology was consulted with practitioners and will be used to revitalize the intermodal transport terminal Nemanice.

The construction of an intermodal transport terminal is imperative from both the political and economic points of view. On the one hand, the state's transport policy, as well as the European Union's transport policy, clearly declares support for environmental modes of transport, which contribute to reducing the negative environmental impact of transport. On the other hand, for functional ecological intermodal transport, the territory must be equipped with the relevant transport infrastructure, in particular, with intermodal transport terminals and their proper connection to the transport network. Nevertheless, only a reasonably constructed terminal can provide desired performance at an adequate cost since especially the terminal's operating cost greatly affects the pricing of services provided by the terminal. Moreover, these costs have a major impact on intermodal transport competitiveness compared to direct road freight transport. Terminal fees must be attractive for customers (shippers, operators, road carriers, etc.), otherwise, the construction of an intermodal transport terminal would be inefficient, and thereby the shifting of freight transport into intermodal transport cannot be expected [16].

From an economic perspective, the intermodal transport terminal construction is substantial mainly with regard to generating new job possibilities, attracting new production plants, helping towards increasing industrial production in the certain territory, improving the transport situation in the area, and possibly enhancing transport performance without burdening the road transport infrastructure and the environment.

The draft methodology provides a reasonable insight into searching for proper terminal elements, from determining the required number of handling devices to specifying the most appropriate type of device, when taking into account the overall economic efficiency. The designed intermodal transport terminal Nemanice will thus be sufficiently equipped in terms of performance and, at the same time, its operation will be economically viable.

\section{Conclusions}

Intermodal transport terminal is regarded the essential element of transport-logistics chains. To ensure the proper and efficient functionality of these chains, it is necessary to build up or modernize these transport hubs so that they do not create bottlenecks in terms of global cargo flows. The design of individual elements of intermodal transport terminal, their layout, and coherence must be based on strict technical and technological requirements. However, it is advisable to utilize multiple exact decision making methods, which can be applied to select the most suitable alternative out of a series of possible solutions. The goal of this manuscript was to assess several variants in terms of revitalization of the Nemanice terminal and identify the most appropriate one by applying different mathematical methods of multi-criteria decision analysis.

To this end, the TOPSIS method as well as the WSA method were used and the final variant ranking is as follows:

- $\quad$ scenario no. 2 as the most suitable option;

- scenario no. 3 as the second-best option;

- scenario no. 1 as the third-best option. 
Eventually, following the previous calculations and investigations, it can be stated that the handling equipment scenario containing two rail-mounted gantry cranes and one reach stacker was determined to be the most matching alternative. In the Nemanice terminal, reach stacker will be operated as an additional mechanism. Its capacity of up to 8-13 tons is sufficient and will be intended to handle empty containers (loading an empty container on the articulated vehicle and its consequent carriage to the customer, or unloading an empty container from the articulated vehicle after the carriage termination and its placing on the depositing area).

The compiled procedure of designing the terminal elements and choosing the appropriate type of handling equipment may be considered as one of the insights into alternative solutions.

Building a network of intermodal transport terminals is a matter of social importance as well. A built-up high-quality intermodal transport infrastructure is being a precondition for an increase in the share of intermodal transport in total transport, no matter whether it is a concern of import, export, or transit. This will help to mitigate the adverse effects of road freight transport, reduce emissions, exhalation, accidents, minimize the number of congestions on international corridors, etc. Consequently, building a high-quality network of intermodal transport terminals is also important from the point of view of ensuring and maintaining a sustainable global transport system.

The issue of intermodal transport terminal renewals has not been based on any unified and comprehensive methodology yet. In the Czech Republic, for instance, this subject followed a variety of examples from Italy, China, or Germany, where, however, different criteria and aspects influencing the final outcome substantially have been taken into account. Some methodologies to propose the procedure of functionalizing various industrial objects are summarized in Section 2 of this research study. Nevertheless, none of them is based on the aspects, mathematical methods used, and criteria being suggested in this manuscript. The fundamental idea of our manuscript was to revitalize the existing defund intermodal object in the most appropriate way in order to serve as many customers as possible in the context of picking-up and distributing the shipments within the terminal attraction circuit to a maximum extent. An efficiently operated transport hub (where an intermodal transport terminal can be included) is an essential prerequisite for ensuring the sustainability of the transport system in the certain territory, and therefore, the proposed methodology for dealing with the modernization of defunct intermodal transport terminals is closely related to the sustainability of freight transport itself, above all, in terms of the sustainable development of freight transport performance in a globalized world.

In view of the aforementioned, it can be declared that such a methodological procedure has not been published yet and may, thus, be deemed as a dissimilar look on options of intermodal transport terminal revitalization.

The possible future subjects to be addressed may include, for example, the detailed financial assessments regarding the revitalization of such intermodal objects as well as the environmental assessment of such issues, possibly, the combination of both cases. The revitalization works could be funded, for instance, by various subsidy programs within the European Union.

Author Contributions: Conceptualization, J.L. and O.S.; methodology, J.L.; validation, J.L. and O.S.; formal analysis, J.L.; investigation, J.L.; resources, J.L. and O.S.; data curation, J.L.; writing-original draft preparation, J.L. and O.S.; writing-review and editing, J.L. and O.S.; visualization, O.S.; supervision, O.S.; project administration, J.L. All authors have read and agreed to the published version of the manuscript.

Funding: This research received no external funding.

Acknowledgments: This manuscript was supported within solving the research project entitled "Autonomous mobility in the context of regional development LTC19009" of the INTER-EXCELLENCE program, the VES 19 INTER-COST subprogram.

Conflicts of Interest: The authors declare no conflict of interest.

\section{References}

1. Novák, J.; Cempírek, V.; Novák, I.; Široký, J. Combined Transportation, 5th ed.; University of Pardubice: Pardubice, Czech Republic, 2015; 339p, ISBN 978-80-7395-948-7. (In Czech) 
2. Osorio-Tejada, J.L.; Llera-Sastresa, E.; Scarpellini, S. A multi-criteria sustainability assessment for biodiesel and liquefied natural gas as alternative fuels in transport systems. J. Nat. Gas Sci. Eng. 2017, 42, 169-186. [CrossRef]

3. Jagelcak, J.; Zamecnik, J.; Kiktova, M. Potential for intermodal transport of chemical goods in Slovakia. In Proceedings of the 18th International Scientific Conference-LOGI 2017, Ceske Budejovice, Czech Republic, 19 October 2017; Book series: MATEC Web of Conferences. Volume 134. art. no. 00021. [CrossRef]

4. Jagelcak, J.; Kubasakova, I. Load distribution in general purpose maritime container and the analysis of load distribution on extendable semitrailer container chassis carrying different types of containers. Nase More 2014, 61, 106-116.

5. Klapita, V. Optimization of logistic chains in the intermodal transport. Logi-Sci. J. Transp. Logist. 2012, 3, $57-64$.

6. Chovancova, M.; Klapita, V. Draft model for optimization of the intermodal transport chains by applying the network analysis. In Proceedings of the 20th International Scientific Conference on Transport Means, Juodkrante, Lithuania, 5-7 October 2016; pp. 112-116.

7. UNECE. European Agreement on Important International Combined Transport Lines and Related Installations (AGTC); Economic Commission for Europe: Geneva, Switzerland, 1991; Available online: https://www.unece. org/trans/wp24/agtc_text.html (accessed on 29 May 2019).

8. Arnold, P.; Peeters, D.; Thomas, I.; Marchand, H. On an optimal location of centres of intermodal transshipment between transport networks: Formulation and extensions. Can. Geogr.-Geogr. Can. 2001, 45, 427-436. [CrossRef]

9. Bergqvist, R.; Tornberg, J. Evaluating locations for intermodal transport terminals. Transp. Plan. Technol. 2008, 31, 465-485. [CrossRef]

10. Lin, C.C.; Chiang, Y.I.; Lin, S.W. Efficient model and heuristic for the intermodal terminal location problem. Comput. Oper. Res. 2014, 51, 41-51. [CrossRef]

11. Macharis, C. A methodology to evaluate potential locations for intermodal barge terminals: A policy decision support tool. In Transport Developments and Innovations in an Evolving World; Book series: Advances in Spatial Science; Springer: Berlin/Heidelberg, Germany, 2004; pp. 211-234. [CrossRef]

12. Roso, V.; Brnjac, N.; Abramovic, B. Inland intermodal terminals location criteria evaluation: The case of Croatia. Transp. J. 2015, 54, 496-515. [CrossRef]

13. Sorensen, K.; Vanovermeire, Ch.; Busschaert, S. Efficient metaheuristics to solve the intermodal terminal location problem. Comput. Oper. Res. 2012, 39, 2079-2090. [CrossRef]

14. Gosasang, V.; Yip, T.L.; Chandraprakaikul, W. Long-term container throughput forecast and equipment planning: The case of Bangkok port. Marit. Bus. Rev. 2018, 3, 53-69. [CrossRef]

15. Othman, M.K.; Abdul Rahman, N.S.F.; Ismail, A.; Saharuddin, A.H. The sustainable port classification framework for enhancing the port coordination system. Asian J. Shipp. Logist. 2019, 35, 13-23. [CrossRef]

16. Iris, C.; Lam, J.S.L. A review of energy efficiency in ports: Operational strategies, technologies and energy management systems. Renew. Sustain. Energy Rev. 2019, 112, 170-182. [CrossRef]

17. Zecevic, S.; Tadic, S.; Krstic, M. Intermodal Transport Terminal Location Selection Using a Novel Hybrid MCDM Model. Int. J. Uncertain. Fuzziness Knowl.-Based Syst. 2017, 25, 853-876. [CrossRef]

18. Krstic, M.; Tadic, S.; Brnjac, N.; Zecevic, S. Intermodal terminal handling equipment selection using a fuzzy multi-criteria decision-making model. Promet-Traffic Transp. 2019, 31, 89-100. [CrossRef]

19. Transport Yearbook. 2017. Available online: https://www.sydos.cz/cs/rocenka-2017/rocenka/htm_cz/index. html (accessed on 1 July 2019). (In Czech).

20. Lizbetinova, L.; Hitka, M.; Kleymenov, M. Motivational preferences of employees in requirements of Czech and Russian transport and logistics enterprises. Nase More 2018, 65, 254-258. [CrossRef]

21. Kolar, P.; Rodrigue, J.P. Container port selection by freight forwarders in central and Eastern Europe hinterland: The case of the Czech Republic. Nase More 2018, 65, 1-7. [CrossRef]

22. Siroky, J.; Schroder, S.; Gasparik, J. Comparison of operational and economic aspects of direct road transport and continental combined transport. Commun.-Sci. Lett. Univ. Zilina 2017, 19, 109-115.

23. Cerna, L.; Zitricky, V.; Danis, J. The methodology of selecting the transport mode for companies on the Slovak transport market. Open Eng. 2017, 7, 6-13. [CrossRef]

24. Venturini, G.; Iris, C.; Kontovas, C.A.; Larsen, A. The multi-port berth allocation problem with speed optimization and emission considerations. Transp. Res. Part D-Transp. Environ. 2017, 54, 142-159. [CrossRef] 
25. MTCR. Ministry of Transport of the Czech Republic. Combined Transport. 2019. Available online: https://www.mdcr.cz/Dokumenty/Kombinovana-doprava-(2) (accessed on 27 October 2019). (In Czech).

26. Abramović, B. Passenger's satisfaction on long distance terminals: Case study city of Zagreb. Period. Polytech. Transp. Eng. 2017, 45, 42-47. [CrossRef]

27. Binova, H.; Jurkovic, M. Methodology of inland ports design as intermodal terminals in the Czech Republic. In Proceedings of the Carpathian Logistics Congress (CLC 2015), Jesenik, Czech Republic, 4-6 November 2015; pp. 126-131, ISBN 978-80-87294-64-2.

28. Nedeliakova, E.; Panak, M.; Kudlac, S. Qualitative approach to increasing the efficiency of intermodal transport. Logi-Sci. J. Transp. Logist. 2015, 6, 90-98.

29. Skrucany, T.; Kendra, M.; Jurkovic, M.; Kalina, T. Environmental comparison of different transport modes. Nase More 2018, 65, 192-196. [CrossRef]

30. Sramkova, E.; Kolar, P.; Hunak, J. Container shipping: The evaluation of quality factors in freight forwarding services. Transp. J. 2018, 57, 258-279. [CrossRef]

31. Zahumenska, Z.; Gasparik, J. Supporting the connection the logistics centers to rail network. In Proceedings of the 12th International Scientific Conference of Young Scientists on Sustainable, Modern and Safe Transport, High Tatras, Slovakia, 31 May-2 June 2017; Book series: Procedia Engineering. Volume 192, pp. 976-981. [CrossRef]

32. Gasparik, J.; Abramovic, B.; Zitricky, V. Research on dependences of railway infrastructure capacity. Teh. Vjesn.-Tech. Gaz. 2018, 25, 1190-1195. [CrossRef]

33. Cempirek, V. New opportunities for intermodal transport in the Czech Republic. Eisenbahningenieur 2007, 58, 37-39.

34. Chocholáč, J.; Sommerauerová, D.; Hyršlová, J. Analysis of combined transport in the Czech Republic in Relation with CSR. In Proceedings of the 21st International Scientific Conference on Transport Means, Juodkrante, Lithuania, 20-22 September 2017; pp. 424-429.

35. Sorensen, K.; Vanovermeire, Ch. Bi-objective optimization of the intermodal terminal location problem as a policy-support tool. Comput. Ind. 2013, 64, 128-135. [CrossRef]

36. Caban, J.; Drozdziel, P.; Vrabel, J.; Sarkan, B.; Marczuk, A.; Krzywonos, L.; Rybicka, I. The Research on ageing of glycol-based Brake Fluids of Vehicles in Operation. Adv. Sci. Technol.-Res. J. 2016, 10, 9-16. [CrossRef]

37. Duan, L.; Tavasszy, L.A.; Rezaei, J. Freight service network design with heterogeneous preferences for transport time and reliability. Transp. Res. Part E Logist. Transp. Rev. 2019, 124, 1-12. [CrossRef]

38. Kovac, M.; Klapita, V. Material Handling in Transport; EDIS: Zilina, Slovakia, 2003. (In Slovak)

39. Kampf, R.; Hlatka, M.; Savin, G. Proposal for optimizing specific distribution routes by means of the specific method of operational analysis. Commun.-Sci. Lett. Univ. Zilina 2017, 19, 133-138.

40. Kampf, R.; Hlatka, M. Modelling a production process using a Sankey diagram and computerized relative allocation of facilities technique (CRAFT). Open Eng. 2019, 9, 444-449. [CrossRef]

41. Di Mascio, P.; Loprencipe, G.; Moretti, L. Technical and economic criteria to select pavement surfaces of port handling plants. Coatings 2019, 9, 126. [CrossRef]

42. Digiesi, S.; Facchini, F.; Mummolo, G. Dry port as a lean and green strategy in a container terminal hub: A mathematical programming model. Manag. Prod. Eng. Rev. 2019, 10, 14-28. [CrossRef]

43. Martinez-Pardo, A.; Garcia-Alonso, L.; Orro, A. The role of the degree of use of the facilities in the port choice process: The Spanish dockside cranes case. Int. J. Shipp. Transp. Logist. 2018, 10, 514-532. [CrossRef]

44. Cantillo, V.; Visbal, J.; Arellana, J. Analysis on the determinants of shipment size and type-of-truck choices using a discrete-continuous hybrid model. Int. J. Shipp. Transp. Logist. 2018, 10, 406-428. [CrossRef]

45. Sabadka, D.; Molnar, V.; Fedorko, G.; Jachowicz, T. Optimization of production processes using the yamazumi method. Adv. Sci. Technol.-Res. J. 2017, 11, 175-182. [CrossRef]

46. Rashidi, K.; Cullinane, K. A comparison of fuzzy DEA and fuzzy TOPSIS in sustainable supplier selection: Implications for sourcing strategy. Expert Syst. Appl. 2019, 121, 266-281. [CrossRef]

47. Dutta, B.; Singha, T.; Goh, M.; Lamata, M.; Verdegay, J. Post factum analysis in TOPSIS based decision making method. Expert Syst. Appl. 2019, 138, 112806. [CrossRef]

48. Ploskas, N.; Papathanasiou, J. A decision support system for multiple criteria alternative ranking using TOPSIS and VIKOR in fuzzy and nonfuzzy environments. Fuzzy Sets Syst. 2019, 377, 1-30. [CrossRef] 
49. Kliestik, T. Optimization of Transport Routes Based on Graph Theory as a Part of Intelligent Transport Systems. In Proceedings of the 17th International Conference on Transport Means, Kaunas, Lithuania, 24-25 October 2013; pp. 308-311.

50. Muravev, D.; Rakhmangulov, A.; Hu, H.; Zhou, H.S. The introduction to system dynamics approach to operational efficiency and sustainability of dry port's main parameters. Sustainability 2019, 11, 2413. [CrossRef]

51. Ardielli, E. Use of TOPSIS method for assessing of good governance in European Union countries. Rev. Econ. Perspect. 2019, 19, 211-231. [CrossRef]

52. Dinçer, S.E. Multi-criteria analysis of economic activity for European Union member states and candidate countries: TOPSIS and WSA applications. Eur. J. Soc. Sci. 2011, 21, 563-572.

53. Li, Y.; Lin, C.; Wang, Y.; Gao, X.; Xie, T.; Hai, R.; Wang, X.; Zhang, X. Multi-criteria evaluation method for site selection of industrial wastewater discharge in coastal regions. J. Clean. Prod. 2017, 161, 1143-1152. [CrossRef]

54. Jozaghi, A.; Alizadeh, B.; Hatami, M.; Flood, I.; Khorrami, M.; Khodaei, N.; Ghasemi Tousi, E. A comparative study of the AHP and TOPSIS techniques for dam site selection using GIS: A case study of Sistan and Baluchestan Province, Iran. Geosciences 2018, 8, 494. [CrossRef]

55. Husáková, N.; Fedorko, G.; Molnár, V.; Honus, S. Creation of an integral model of supply and distribution as a system for operative planning and scheduling in logistics. In Proceedings of the 16th International Multidisciplinary Scientific GeoConference, SGEM, Albena, Bulgaria, 30 June-6 July 2016; Volume 2, pp. 187-194. [CrossRef]

56. Wicher, P.; Zapletal, F.; Lenort, R. Sustainability performance assessment of industrial corporation using fuzzy analytic network process. J. Clean. Prod. 2019, 241, 118132. [CrossRef]

57. Wondim, T.T.; Dzwairo, B. A scenario-based multiple attribute decision-making approach for site selection of a wastewater treatment plant: Bahir Dar city (Ethiopia) case study. Water SA 2018, 44, 782-794. [CrossRef]

58. Siqueira, G.A.; Leal, I.C.; da Cunha, L.C.; Guimaraes, V.D.; Guabiroba, R.C.D. Analysis of technical efficiency and eco-efficiency in container terminals. Int. J. Shipp. Transp. Logist. 2017, 9, 562-579. [CrossRef]

(C) 2020 by the authors. Licensee MDPI, Basel, Switzerland. This article is an open access article distributed under the terms and conditions of the Creative Commons Attribution (CC BY) license (http://creativecommons.org/licenses/by/4.0/). 